\title{
Harga Diri Seksual, Kompulsivitas Seksual, dan Perilaku Seks Berisiko pada Orang dengan HIV/AIDS
}

\author{
Wahyu Rahardjo ${ }^{1}$ \\ Fakultas Psikologi Universitas Gunadarma, Depok, Jawa Barat \\ Irfan Irwansyah Hutagalung \\ Save Us Foundation, Tangerang, Banten
}

\begin{abstract}
The aim of this study was to measure the role of sexual self-esteem, the general and the specific one which describe the sexual competence, and sexual compulsivity to risky sexual behavior. The participants of this research are 84 men and women with HIV/AIDS. This is a quantitative research using path analysis. The result shows that the empirical model has goodness of fit which is mean fit with the data collected. This finding shows the role of sexual self-esteem and sexual compulsivity to risky sexual behavior. Another finding is fact that sexual self-esteem that describe in sexual competence has more significant influence on risky sexual behavior.

Keywords: sexual self-esteem, sexual kompulsivity, risky sexual behavior
\end{abstract}

Abstrak. Tujuan dari penelitian ini adalah untuk mengukur pengaruh harga diri seksual, baik yang sifatnya umum maupun yang spesifik mengenai kompetensi seksual, dan juga kompulsivitas seksual terhadap perilaku seks berisiko seperti hubungan seks usia dini, jumlah pasangan seks, dan seks dengan orang asing yang dilakukan oleh orang dengan HIV/AIDS. Partisipan penelitian ini berjumlah 84 orang pria dan wanita dengan HIV/AIDS. Penelitian ini merupakan penelitian kuantitaif dengan menggunakan analisis jalur. Hasil penelitian memperlihatkan bahwa model empiris yang didapatkan memiliki goodness of fit atau cocok dengan data. Artinya, harga diri seksual dan kompulsivitas seksual memiliki peran terhadap dilakukannya perilaku seks berisiko pada orang dengan HIV/AIDS. Temuan lainnya adalah bahwa harga diri seksual dalam hal kompetensi seksual memiliki peran lebih banyak dalam memengaruhi individu melakukan perilaku seks berisiko.

Kata kunci: harga diri seksual, kompulsivitas seksual, perilaku seks berisiko

Penyebaran HIV/AIDS menjadi masalah yang kini dihadapi oleh dunia, dan tidak hanya menjadi permasalahan milik beberapa negara saja. Di Indonesia, peningkatan jumlah individu yang terpapar HIV/AIDS (lebih sering disebut sebagai ODHA) juga tergolong mencengangkan dan memprihatinkan. Indonesia disebut sebagai negara yang mengalami peningkatan jumlah orang dengan $\mathrm{HIV} /$ AIDS tertinggi di ASEAN sejak 2001

${ }^{1}$ Korespondensi mengenai isi artikel ini dapat dilakukan melalui: wahyu_rahardjo@yahoo.com hingga sekarang (Kebijakan AIDS Indonesia, 2015). Keadaan ini tentu memaksa pemerintah dan banyak institusi yang berkepentingan bekerja keras untuk menekan laju pertumbuhan pengidap HIV/ AIDS di Indonesia.

Sosialisasi dan pendampingan terhadap orang dengan HIV/AIDS sangat diperlukan bukan hanya untuk menguatan sisi psikologis mereka tetapi juga pembinaan agar keterlibatan terhadap perilaku seks berisiko bisa ditekan sehingga mengurangi kemungkinan penyebaran 
virus tersebut. Sementara itu, perilaku seks berisiko sendiri pada dasarnya dilakukan oleh banyak kelompok, bukan hanya mereka yang sudah terinfeksi HIV/AIDS saja. Hal ini terjadi karena banyak yang memandang rendah perilaku seks aman (Lewis, Litt, Cronce, Blayne, \& Gilmore, 2014). Pada titik ini, tentu menjadi penting artinya untuk memahami perilaku seks berisiko yang mungkin masih dilakukan oleh banyak orang dengan HIV/AIDS.

Perilaku seks berisiko adalah aktivitas seksual yang dilakukan dengan konseksuensi bukan hanya kehamilan yang tidak diinginkan tetapi juga terpapar HIV/AIDS. Beberapa aktivitas seks yang tergolong ke dalam perilaku seks berisiko adalah hubungan seks usia dini, banyaknya pasangan seks yang dimiliki, inkonsistensi penggunaan kondom, dan hubungan seks dengan orang asing atau orang yang belum diketahui secara pasti status kesehatan seksualnya (Rahardjo, 2013).

Beberapa hal dianggap memengaruhi individu dalam melakukan perilaku seks berisiko, di mana dua di antaranya adalah harga diri seksual dan kompulsivitas seksual. Harga diri secara umum telah lama dianggap memengaruhi perilaku seks berisiko. Secara spesifik, harga diri seksual merupakan penilaian positif individu tentang seksualitas yang dimiliki individu (Snell, 1998). Harga diri seksual berkaitan dengan kepuasan seks (McCabe \& Taleporos, 2003), hal ini kerap membawa individu untuk terdorong lebih ekspresif dalam melakukan aktivitas seksual.

Di sisi lain, kompulsivitas seksual di dalam beberapa penelitian empiris telah terbukti berpengaruh secara langsung terhadap perilaku seks berisiko (Shuper, Joharchi, \& Rehm, 2014; Smolenski, Ross, Risser, \& Rosser, 2009). Kompulsivitas seksual dianggap menyebabkan individu menjadi kian permisif, terutama dalam melakukan perilaku seks berisiko sehingga memunculkan efek domino seperti permasalahan kesehatan psikososial dan peningkatan kasus paparan HIV/AIDS (Parsons, Grov, \& Golub, 2012). Kompulsivitas seksual sendiri, di dalam memengaruhi perilaku seks berisiko bukan hanya terjadi pada pria yang dipandang permisif dalam seksualitas, namun juga pada wanita (Stupiansky, Reece, Middlestat, Finn, \& Sherwood-Laughlin, 2009).

\section{Kompulsivitas Seksual}

Kompulsivitas seksual pada dasarnya merupakan permasalahan klinis individu. Kompulsivitas seksual merupakan keadaan di mana individu mengalami permasalahan dalam mengendalikan pikiran, perasaan, dan perilaku seksualnya (Berberovic, 2013). Pada titik ini, kendali diri dikatakan memiliki peran yang krusial dalam konsep kompulsivitas seksual (Giugliano, 2008; Kalichman \& Cain, 2004). Secara lebih lanjut juga ditekankan oleh Berberovic (2013) bahwa berkurangnya kendali atas perilaku seks yang dilakukan mengakibatkan individu terus terlibat dalam perilaku tersebut meskipun mengetahui konsekuensi negatifnya.

Konsekuensi dari kompulsivitas seksual yang dirasakan tentu bukan hanya fisik seperti terinfensi penyakit menular seksual karena permisivitas seksual yang dilakukan, tetapi juga pada aspek sosial dan emosi, dan bahkan spiritual serta keuangan (McBride, Reece, \& Sanders, 2008). Temuan Reece dan Dodge (2004) memperlihatkan bahwa permisivitas seksual yang muncul karena kompulsivitas seksual tersebut membuat individu terintervensi kehidupan sosialnya, termasuk penurunan tanggung jawab dan berkurangnya aktivitas keseharian. 


\section{Harga Diri Seksual}

Harga diri seksual adalah pandangan positif individu tentang bagaimana dirinya dapat melakukan dan menikmati aktivitas seksual tertentu (Brassard, Dupuy, Bergeron, \& Shaver, 2015). Adapun Mayers, Heller, dan Heller (2003) melihat harga diri seksual sebagai produk masa lalu yang dimanifestasikan pada masa kini dan berpengaruh terhadap pencarian informasi terkait seksualitas dan memandu bagaimana individu ingin berperilaku secara seksual. Secara lebih lanjut Brassard et al. (2015) menyatakan bahwa konstruk harga diri seksual secara empiris memiliki korelasi dengan banyak variabel terkait seksualitas seperti relasi seks, dan kepuasan seks. Namun, kemungkinan hal ini dapat terjadi ketika konstruk harga diri seksual dipandang sebagai sesuatu yang lebih umum dan kurang spesifik. Harga diri seksual secara umum merupakan konstruk yang dibawa oleh Snell (1998) di dalam beberapa penelitian seksnya.

Di sisi lain, harga diri sendiri ditemukan oleh banyak penelitian seks yang lebih spesifik seperti perilaku seks berisiko sebagai salah satu variabel penyebabnya (Boden \& Horwood, 2006; Robinson, Holmbeck, \& Paikoff, 2007). Bahkan dalam kasus yang lebih spesifik juga ditemukan bahwa harga diri seksual berkaitan dengan perilaku seks berisiko yang dilakukan (van Bruggen, Runtz, \& Kadlec, 2006). Hal ini mungkin terjadi karena konstruk harga diri seksual yang lebih menitikberatkan pada kompetensi seksual. Artinya pengaruh yang muncul bisa jadi bersifat positif ketika individu merasa berharga karena memiliki kompetensi seksual maka menjadi semakin permisif dalam berbagai aktivitas seksual (Snell, Fisher, \& Schuh, 1992).

\section{Perilaku Seks Berisiko}

Perilaku seks berisiko merupakan aktivitas seksual yang dilakukan oleh individu dengan risiko terpapar HIV/ AIDS. Sederhananya, risiko perilaku seks ini bukan hanya sekedar kehamilan yang tidak diinginkan, melainkan juga terinfeksi penyakit menular seksual, termasuk terpapar HIV/AIDS.

Rahardjo (2013) menyatakan bahwa pada dasarnya, perilaku seks berisiko dapat dilihat pada empat aktivitas yang berbeda. Pertama adalah hubungan seks usia dini. Hubungan seks usia dini ditengarai memberikan dasar penting bagi terbentuknya perilaku-perilaku seks berisiko berikutnya yang mungkin dilakukan individu di masa yang akan datang (Binggeli, 2005). Individu yang sudah melakukan hubungan seks semenjak usia dini dianggap lebih mudah untuk terlibat dalam aktivitas seks berisiko lainnya.

Aktivitas seks berisiko berikutnya adalah jumlah pasangan seks. Kepemilikan pasangan seks dalam jumlah banyak merupakan hal yang lazim dijumpai baik pada pria maupun wanita, apa pun orientasi seksnya (Binson et al., 2001; He et al., 2006). Kemudian yang ketiga adalah hubungan seks dengan orang asing atau dengan siapa individu paling sering terlibat aktivitas seks berisiko. Ini adalah bentuk seks kasual di mana individu bisa berhubungan seks dengan orang yang baru ditemui, atau teman yang sudah dikenal namun tidak diketahui secara pasti status kesehatan seksnya, apakah teman tersebut HIV positif atau HIV negatif (Grello, Welsh, \& Harper, 2006).

Berdasarkan penjelasan yang telah disebutkan sebelumnya maka hipotesis penelitian ini adalah terdapat peran harga diri seksual dan juga kompulsivitas seksual terhadap perilaku seks berisiko pada orang dengan HIV/AIDS. 


\section{Metode}

Variabel-variabel yang digunakan di dalam penelitian ini adalah harga diri seksual sebagai variabel eksogen, kompulsivitas seksual sebagai variabel mediator, dan perilaku seks berisiko sebagai variabel endogen. Perilaku seks berisiko dipaparkan menjadi tiga variabel yang terpisah sebagai konsekuensi dari sifat multidimensi yang melekat, yaitu hubungan seks usia dini, jumlah pasangan seks, dan seks dengan orang asing.

Penelitian ini melibatkan 84 orang partisipan ODHA atau orang dengan HIV/AIDS yang tinggal di kota Salatiga, Jepara, Yogyakarta, dan Jakarta. Seluruh partisipan penelitian adalah individu lajang yang belum menikah. Partisipan ditemui saat pertemuan internal baik dalam suasana formal maupun informal yang diikuti oleh salah satu peneliti sebagai pegiat kesehatan komunitas HIV/ AIDS. Pertimbangan ini diambil karena perilaku seks berisiko pada individu lajang biasanya lebih permisif serta pertimbangan tambahan bahwa individu yang sudah menikah biasanya hanya atau lebih banyak berhubungan seks dengan suami atau istrinya.

Dari jumlah tersebut, 55 orang di antaranya adalah pria, dan 39 sisanya merupakan partisipan wanita. Mayoritas partisipan mengaku memiliki orientasi seksual sebagai heteroseksual ( $\mathrm{n}=44$; $52.38 \%)$, diikuti oleh gay $(n=21 ; 25 \%)$, biseksual $(n=15 ; 17.85 \%)$, dan lesbian $(n=$ $4 ; 4.76 \%)$. Usia partisipan terentang antara 22 hingga 51 tahun $(M=32.64 ; S D=5.86)$.

Harga diri seksual. Harga diri seksual adalah kecenderungan umum bagi individu untuk melakukan evaluasi secara positif terhadap kapasitas dirinya dalam melakukan dan mengalami perilaku seksual tertentu secara memuaskan (Snell,
1998). Skala harga diri seksual yang digunakan di dalam penelitian ini disusun berdasarkan sintesis cukilan skala milik Snell, Fisher, dan Schuh (1992) yang menitikberatkan terhadap persepsi akan kompetensi seksualitas (contoh aitem, "Kemampuan seks saya lebih baik dari kebanyakan orang"), dan skala milik Snell (1998) yang melihat harga diri seksual secara lebih umum (contoh aitem, "Saya memiliki kebanggaan diri mengenai cara saya memenuhi kebutuhan seks saya"). Skala ini memiliki aitem sejumlah 10 butir dengan reliabilitas sebesar 0.784 .

Kompulsivitas seksual. Kompulsivitas seksual merupakan suatu kebutuhan yang sifatnya mendesak dalam menampilkan perilaku seksual tertentu yang sifatnya mendalam dan repetitif (Kalichman \& Rompa, 1995). Skala kompulsivitas seksual yang digunakan dalam penelitian ini menggunakan skala milik Kalichman (2011). Salah satu contoh aitemnya adalah "Gairah saya terhadap seks sudah mengganggu kegiatan sehari-hari saya". Pilihan jawaban untuk skala ini terentang 1-5 mulai dari Sangat Sesuai hingga Sangat Tidak Sesuai. Skala ini memiliki aitem sejumlah 10 butir dengan reliabilitas sebesar 0.954 .

Perilaku seks berisiko. Perilaku seks berisiko adalah keterlibatan individu dalam aktivitas seksual yang memungkinkan dirinya terpapar penyakit seksual seperti HIV/AIDS (Guin, 2005). Perilaku seks berisiko di dalam penelitian ini dilihat dari tiga hal, yaitu (1) hubungan seks usia dini, (2) jumlah pasangan seks, dan (3) hubungan seks dengan orang asing atau orang yang tidak diketahui secara pasti status kesehatan seksualnya. Hubungan seks usia dini diketahui dari kolom isian singkat melalui pertanyaan "Anda melakukan hubungan seksual pertama kali usia ..... tahun". Demikian 
pula jumlah pasangan seks diketahui melalui kolom isian singkat melalui pertanyaan "Di dalam kurun waktu 6 bulan terakhir, Anda melakukan hubungan seks vaginal/anal dengan ...... orang". Sementara itu, hubungan seks dengan orang asing diketahui dengan "Dengan siapa Anda paling sering berhubungan seks dalam kurun waktu 6 bulan terakhir?" dan pilihannya jawabannya adalah kekasih, teman, dan pekerja seks komersial.

Pertimbangan kurun waktu enam bulan terakhir adalah merupakan rentang waktu paling ideal dalam mencakup variasi jumlah pasangan seks dan pertimbangan memori dari partisipan mengenai jumlah pasangan seksnya. Jika menggunakan kriteria tiga bulan dianggap terlalu sebentar dan 12 bulan dianggap terlalu lama. Beberapa penelitian mengenai perilaku seks berisiko sebelumnya menggunakan kriteria enam bulan sebagai salah satu kriteria inklusinya (Cooperman, Arnsten, \& Klein, 2007; Neilands, Steward, \& Choi, 2008; Rahardjo, 2013; Rahardjo, Saputra, \& Hapsari, 2015).

Di dalam penelitian ini, teknik analisis data yang dilakukan yang paling utama adalah dengan menggunakan analisis jalur dan uji perbedaan untuk beberapa kategori lainnya.

Tabel 1

Rerata Empirik untuk Semua Variabel

\begin{tabular}{|c|c|c|c|c|c|}
\hline & $\begin{array}{c}\text { Skor } \\
\text { Minimum }\end{array}$ & $\begin{array}{c}\text { Skor } \\
\text { Maksimum }\end{array}$ & $\begin{array}{l}\text { Rerata } \\
\text { Empirik }\end{array}$ & $\begin{array}{c}\text { Standar Deviasi } \\
\text { Empirik }\end{array}$ & Kategori \\
\hline $\begin{array}{l}\text { Harga diri seksual: } \\
\text { Persepsi umum }\end{array}$ & 7 & 23 & 16.99 & 3.79 & Sedang \\
\hline $\begin{array}{l}\text { Harga diri seksual: } \\
\text { kompetensi seksual }\end{array}$ & 9 & 24 & 14.15 & 3.90 & Sedang \\
\hline Kompulsivitas seksual & 11 & 50 & 32.75 & 8.12 & Sedang \\
\hline $\begin{array}{l}\text { Usia hubungan seks } \\
\text { pertama kali }\end{array}$ & 12 & 28 & 18.39 & 2.60 & - \\
\hline Jumlah pasangan seks & 1 & 10 & 2.69 & 1.98 & - \\
\hline
\end{tabular}


Berdasarkan Tabel 2 dapat dilihat bahwa rangsangan pasangan seks adalah alasan yang paling banyak disebut sebagai hal yang menyebabkan individu melakukan hubungan seks pertama kali. Alasan-alasan lain yang mengikuti adalah ketidakmampuan menahan gairah seks, rasa ingin tahu terhadap seksualitas, kemauan sendiri, ajakan dan pengaruh teman, pengaruh alcohol, pengaruh obatobatan terlarang, dan cinta. Sementara itu jika dilihat alasan mengapa tetap melakukan perilaku seks berisiko dalam keadaan sudah tahu bahwa dirinya terpapar HIV/AIDS, maka hal yang paling banyak disebut adalah untuk menyalurkan gairah seks, diikuti oleh sebagai ekspresi cinta dan kasih sayang, rangsangan pasangan seks, prinsip bahwa seks merupakan sesuatu yang harus dinikmati, pengaruh teman, eksperimen seksualitas, gaya hidup, dan pelarian dari masalah hidup. Berdasarkan Tabel 2 juga dapat dilihat bahwa kebutuhan menyalurkan gairah seks menjadi alasan yang paling sering disebut mengapa individu tetap melakukan perilaku seks berisiko.

Berdasarkan Tabel 3 tampak bahwa hal yang paling sering disebut oleh partisipan mengenai alasan mengapa pernah tidak menggunakan kondom saat berhubungan seks adalah karena kondom dianggap mengurangi kenikmatan saat berhubungan seks. Alasan-alasan lainnya adalah karena malas menggunakan, dianggap mengganggu proses hubungan seks yang sedang dilakukan, pasangan seks tidak menghendaki pemakaian kondom, persepsi agar lebih menyatu dengan pasangan, dan persepsi supaya pasangan tidak kehilangan kepercayaan terhadap individu.

Tabel 2

Paparan Alasan Partisipan Pertama Kali Berhubungan Seks dan Mengapa Tetap Melakukan Perilaku Seks Berisiko Hingga Saat Ini

\begin{tabular}{lclc}
\hline \multicolumn{1}{c}{$\begin{array}{c}\text { Alasan Pertama Kali } \\
\text { Berhubungan Seks }\end{array}$} & $\begin{array}{c}\text { Disebut } \\
\text { Sebanyak }(n) / \\
\text { Persentase }\end{array}$ & $\begin{array}{c}\text { Alasan Tetap Melakukan Perilaku } \\
\text { Seks Berisiko } \\
\text { Hingga Saat Ini }\end{array}$ & $\begin{array}{c}\text { Disebut } \\
\text { Sebanyak }(n) \\
\text { / Persentase }\end{array}$ \\
\hline Rangsangan pasangan seks & $26 / 30.95 \%$ & Menyalurkan gairah seks & $40 / 47.61 \%$ \\
Tidak bisa menahan gairah seks & $25 / 29.76 \%$ & Ekspresi cinta dan kasih sayang & $20 / 23.80 \%$ \\
Rasa ingin tahu & $12 / 14.28 \%$ & Rangsangan pasangan seks & $12 / 14.28 \%$ \\
Kemauan sendiri & $7 / 8.33 \%$ & Prinsip bahwa seks harus dinikmati & $4 / 4.76 \%$ \\
Ajakan dan pengaruh teman & $6 / 7.14 \%$ & Pengaruh teman & $2 / 2.38 \%$ \\
Pengaruh alkohol & $5 / 5.95 \%$ & Eksperimen seksualitas & $2 / 2.38 \%$ \\
Pengaruh obat-obatan terlarang & $2 / 2.38 \%$ & Gaya hidup & $2 / 2.38 \%$ \\
Cinta & $1 / 1.19 \%$ & Pelarian masalah & $2 / 2.38 \%$ \\
\hline
\end{tabular}

Tabel 3

Alasan Mengapa Pernah Tidak Menggunakan Kondom Saat Berhubungan Seks

\begin{tabular}{lcc}
\hline \multicolumn{1}{c}{ Alasan } & Disebut Sebanyak $(n)$ & Persentase \\
\hline Mengurangi kenikmatan saat berhubungan seks & 35 & $41.66 \%$ \\
Malas menggunakan & 19 & $22.61 \%$ \\
Mengganggu proses hubungan seks yang sedang & 14 & $16.66 \%$ \\
dilakukan & & \\
Pasangan seks tidak menghendaki & 10 & $11.90 \%$ \\
Supaya lebih menyatu dengan pasangan & 5 & $5.95 \%$ \\
Supaya pasangan tidak kehilangan kepercayaan & 1 & $1.19 \%$ \\
\hline
\end{tabular}


Adapun analisis jalur memperlihatkan bahwa model yang dibangun fit dengan data. Chi-Square yang diperoleh oleh model analisis jalur ini adalah sebesar 7.545 dan probabilitas sebesar $0.056(p>$ .05). Artinya, harga diri seksual secara umum maupun yang berkaitan dengan kompetensi seksual, beserta kompulsivitas seksual berpengaruh terhadap usia hubungan seks pertama kali, jumlah pasangan seks dalam kurun waktu enam bulan terakhir, dan seks dengan orang asing. Penjelasan yang lebih jelas dapat dilihat pada Gambar 1.

Ketika dipaparkan mengenai pengaruh masing-masing variabel maka dapat terlihat bahwa tidak semua garis dalam model memperlihatkan pengaruh yang signifikan. Beberapa yang tidak signifikan adalah pengaruh harga diri secara umum terhadap usia hubungan seks pertama kali dan seks dengan orang asing, dan harga diri spesifik mengenai kompetensi seksual terhadap kompulsivitas seksual dan usia hubungan seks pertama kali.

Sementara itu, beberapa pengaruh yang signifikan adalah (1) harga diri seksual secara umum kepada kompulsivitas seksual dan jumlah pasangan seks yang dimiliki dalam kurun waktu enam bulan terakhir, (2) harga diri seksual dalam hal kompetensi seksual terhadap jumlah pasangan seks dan seks dengan orang asing, dan (3) kompulsivitas seksual terhadap usia hubungan seks pertama kali, jumlah pasangan seks dalam kurun waktu enam bulan terakhir, dan seks dengan orang asing. Guna mendapatkan penjelasan yang lebih kongkrit dapat dilihat paparan data pada Tabel 4 dan Tabel 5.

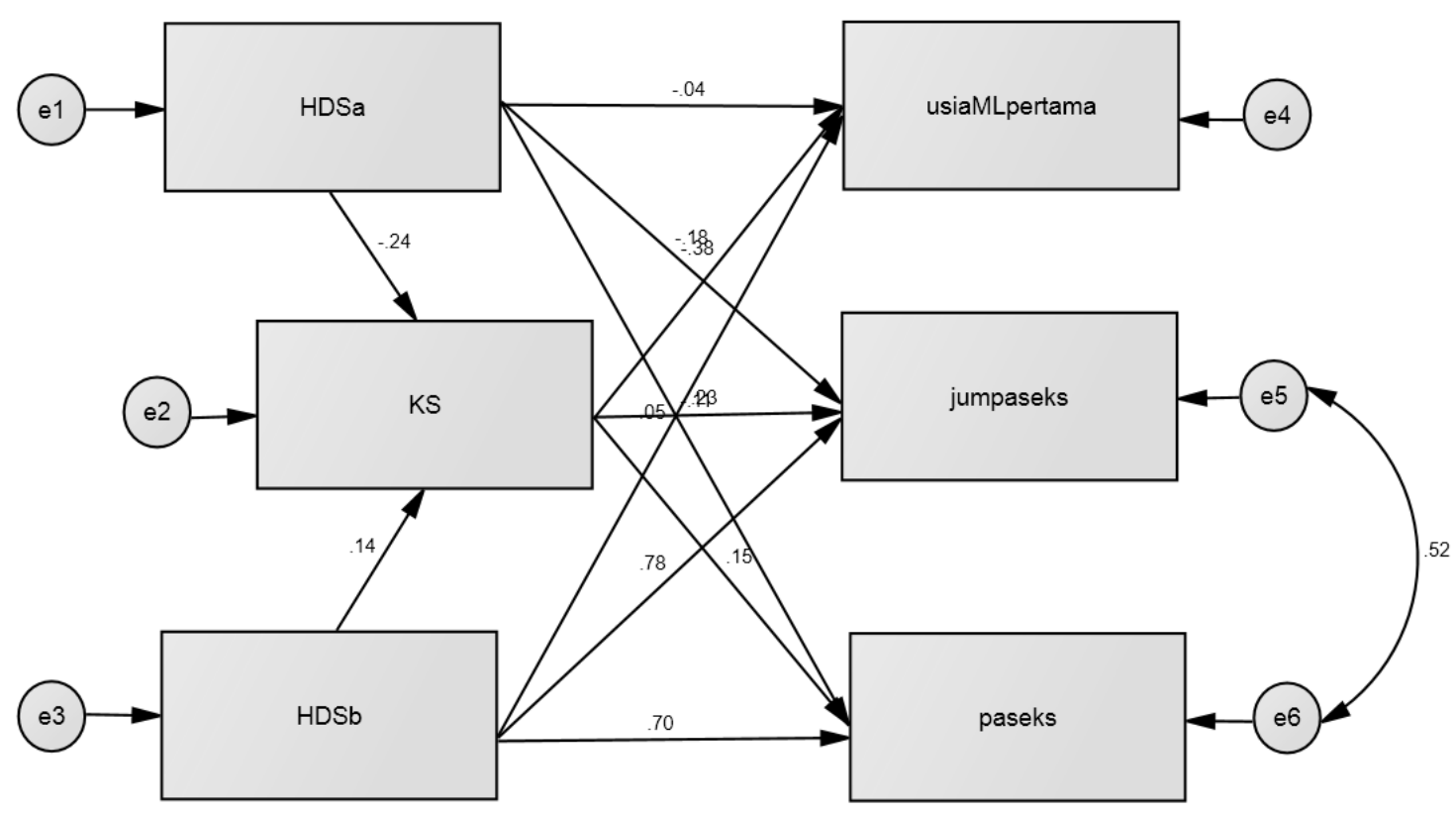

Gambar 1. Model Analisis Jalur 
Tabel 4

Deskripsi Bobot Regresi Antar Variabel terutama untuk Signifikansi

\begin{tabular}{llrrrrr}
\hline & & Estimate & S.E. & \multicolumn{1}{c}{ C.R. } & P & Label \\
\hline KS & $<---$ HDSa & -.516 & .224 & -2.299 & .021 & \\
KS & $<---~ H D S b$ & .298 & .218 & 1.371 & .170 & \\
usiaMLpertama & $<---~ H D S a$ & -.027 & .075 & -.357 & .721 & \\
jumpaseks & $<---~ H D S a$ & -.090 & .027 & -3.314 & $* * *$ & \\
paseks & $<---$ HDSa & -.015 & .010 & -1.460 & .144 & \\
usiaMLpertama & $<---$ KS & -.128 & .035 & -3.602 & $* * *$ & \\
jumpaseks & $<---$ KS & .055 & .013 & 4.261 & $* * *$ & \\
paseks & $<---$ KS & .010 & .005 & 1.994 & .046 & \\
paseks & $<---$ HDSb & .093 & .010 & 9.537 & $* * *$ & \\
jumpaseks & $<---$ HDSb & .384 & .026 & 14.882 & $* * *$ & \\
usiaMLpertama & $<---$ HDSb & .035 & .071 & .499 & .618 & \\
\hline
\end{tabular}

Tabel 5

Bobot Regresi Terstandardisasi Antar Variabel

\begin{tabular}{lllc}
\hline & & & Estimate \\
\hline KS & $<---$ & HDSa & -.242 \\
KS & $<---$ & HDSb & .144 \\
usiaMLpertama & $<---$ & HDSa & -.037 \\
jumpaseks & $<---$ & HDSa & -.178 \\
paseks & $<---$ & HDSa & -.109 \\
usiaMLpertama & $<---$ & KS & -.383 \\
jumpaseks & $<---$ & KS & .232 \\
paseks & $<---$ & KS & .151 \\
paseks & $<---$ & HDSb & .700 \\
jumpaseks & $<---$ & HDSb & .785 \\
usiaMLpertama & $<---$ & HDSb & .051 \\
\hline
\end{tabular}

Hasil penelitian juga memperlihatkan ada perbedaan kompulsivitas seksual berdasarkan jenis kelamin $(t=6.223$; $p<$ .00) di mana partisipan pria memiliki skor kompulsivitas seksual lebih tinggi $(M=$ 36.07; $S D=7.02$ ) dibandingkan partisipan wanita $(M=26.45 ; S D=6.15)$.

\section{Diskusi}

Rerata usia hubungan seks pertama kali yang berada di angka 18.39 tahun mengindikasikan bahwa hubungan seks pertama kali tersebut dilakukan pada usia sekolah menengah atas. Hal ini cukup senada dengan temuan penelitianpenelitian sebelum di Indonesia yang merujuk pada angka 16-18 tahun (Rahardjo, 2009; 2011; 2011a; Rahardjo \& Salve, 2014). Sebagai temuan, angka ini berfluktuasi dari satu penelitian ke penelitian lainnya, hanya saja masih berada dalam ruang lingkup usia sekolah dan mahasiswa tingkat awal. Hal ini jelas menandakan bahwa bagi pelaku perilaku seks aktif, sudah menjadi kelaziman ketika 
usia hubungan seks pertama kali terjadi di masa di mana terdapat puncak kematangan seks dan kuatnya peran teman sebaya.

Alasan berhubungan seks pertama kali karena rangsangan pasangan seks sebagai jawaban yang paling sering muncul menarik untuk dicermati. Temuan ini sedikit berbeda dengan penelitian sebelumnya yang menyatakan bahwa keinginan untuk menyalurkan gairah seks, kemauan sendiri, dan rasa ingin tahu adalah beberapa alasan yang paling sering disebut (Rahardjo, 2008; 2013). Hal ini mungkin terjadi jika individu memiliki pasangan seks yang juga memiliki gairah seks yang juga tinggi sehinggi menjadi pemicu terjadinya hubungan seks pertama kali.

Sementara itu munculnya pernyataan mengenai kebutuhan penyaluran gairah seks sebagai jawaban yang paling banyak disebut atas pertanyaan mengapa partisipan masih melakukan perilaku seks berisiko juga menarik untuk dicermati. Hal ini semakin menguatkan peran kompulsivitas seksual di mana individu memiliki kebutuhan yang besar untuk melakukan hubungan seks secara rutin dan repetitif karena kurangnya kendali diri (Barberovic, 2013).

Hasil penelitian ini mengenai alasan mengapa individu pernah tidak menggunakan kondom saat berhubungan seks senada dengan temuan Rahardjo (2013) yang juga mengungkapkan bahwa kondom masih dianggap sebagai sesuatu yang mengurangi kenikmatan seks sehingga banyak individu menjadi malas menggunakannya. Alasan ini merupakan alasan yang sangat lazim disebutkan oleh banyak pelaku perilaku seks berisiko (Simbayi et al., 2004). Sikap malas menggunakan kondom terutama ditengah proses hubungan seks terjadi karena hal itu dianggap dapat merusak suasana hati individu serta ritme hubungan seks karena tuntutan jeda pemakaian (Fernandez-Esquer et al., 2004).

Secara lebih lanjut, model analisis jalur pada penelitian ini memperlihatkan bahwa harga diri seksual, baik secara umum dan khusus dalam hal kompetensi seksual, beserta kompulsivitas seksual dapat memengaruhi perilaku seks berisiko yang dilakukan orang dengan HIV/AIDS dalam hal hubungan seks usia dini, jumlah pasangan seks dalam kurun waktu enam bulan terakhir, dan hubungan seks dengan orang asing.

Jika dilihat pengaruh pada setiap variabel maka dapat dilihat beberapa hasil yang menarik. Harga diri seksual secara umum yang melihat pada bagaimana individu mempersepsikan keberhargaan seksualitasnya, bagaimana persepsi dalam menangani permasalahan seksualitas, memiliki pengaruh yang negatif terhadap kompulsivitas seksual. Hal ini berarti, jika individu memandang dirinya secara utuh berharga dalam hal seksualitas maka dapat mengurangi kompulsivitas seksual yang dirasakan.

Hal yang relatif sama juga ditemui pada pengaruh negatif harga diri seksual secara umum terhadap jumlah pasangan seks yang dimiliki dalam kurun waktu enam bulan terakhir. Artinya, ketika individu memandang dirinya sebagai sosok yang berharga secara seksualitas maka cenderung lebih mudah menahan diri untuk melampiaskan dorongan seks yang dirasakan melalui perilaku bergantiganti pasangan seks. Temuan yang nyaris senada diungkapkan oleh Schick, Calabrese, Rima, dan Zucker (2010) yang menyatakan bahwa harga diri seksual secara umum dapat meningkatkan motivasi untuk melakukan seks aman. Artinya, jika seseorang menganggap dirinya berharga secara seksual maka cenderung 
berusaha untuk tidak terlalu jauh terlibat dalam perilaku seks berisiko.

Sementara itu, harga diri seksual yang berkaitan dengan kompetensi seksual memiliki pengaruh secara langsung terhadap perilaku seks berisiko. Artinya semakin merasa hebat individu terhadap kemampuan seksualnya maka akan semakin banyak jumlah pasangan seks yang dimiliki dan semakin tinggi risiko keterlibatan individu untuk berhubungan seks dengan orang asing atau orang yang tidak diketahui secara pasti status kesehatan seksualnya.

Permasalahan pada harga diri seksual dapat menyebabkan kemampuan individu dalam mengalami suatu pengalaman yang memuaskan menjadi terbatas (Mayers, Heller, \& Heller, 2003). Hal ini mendorong individu untuk berusaha lebih keras agar kebutuhan seksualitasnya menjadi terpuaskan dengan aktivitas seksual yang sifatnya repetitif dan berisiko seperti banyaknya pasangan seks yang juga berpengaruh terhadap banyaknya hubungan seks yang dilakukan dalam kurun waktu enam bulan terakhir dengan penggunaan kondom yang tidak konsisten.

Harga diri seksual memengaruhi skrip seksual dalam benak individu sehingga memandang beberapa aktivitas seksual sebagai sesuatu yang sifatnya normatif dan juga permisif (Kvalem, Traeen, Lewin, \& Stulhofer, 2014). Individu yang memiliki harga diri yang rendah akan merasa hebat secara seksual jika bisa memiliki pasangan seks dalam jumlah banyak. Individu yang merasa memiliki kemampuan seks yang hebat juga memiliki kecenderungan untuk berhubungan seks dengan banyak orang sebagai penegasan mengenai keberhargaan seksual yang dimiliki.

Di sisi lain, kompulsivitas seksual memiliki pengaruh terhadap hubungan seks usia dini, banyaknya pasangan seks yang dimiliki dalam kurun waktu enam bulan terakhir, dan kecenderungan melakukan hubungan seks dengan orang asing. Studi Schnarrs et al. (2010) menjelaskan bahwa kompulsivitas seksual berpengaruh positif terhadap banyaknya pasangan seks yang dimiliki baik pada pria maupun wanita. Ketidakmampuan mengendalikan dorongan seks menyebabkan individu berusaha melampiaskan melalui aktivitas seksual tertentu yang sifatnya eksesif, seperti kepemilikan pasangan seks dalam jumlah yang banyak, terutama dengan orang yang tidak diketahui secara pasti status kesehatan seksnya, tidak konsisten menggunakan kondom, hingga penggunaan obat-obatan terlarang saat berhubungan seks (Woolf-King et al., 2013).

Pria memang terbukti memiliki kompulsivitas seksual lebih kuat dibandingkan wanita (Dodge, Reece, Cole, \& Sandfort, 2004). Hal ini bisa terjadi salah satunya dikarenakan peran hormon testosteron pada pria yang memang sangat memengaruhi dorongan seks atau libido pria (Aluja \& Garcia, 2005). Tingginya dorongan seks inilah yang kemudian terkait dengan kompulsivitas seksual sehingga sebagai konsekuensinya maka individu harus menyalurkannya melalui aktivitas seksual tertentu secara berulang kali (Parsons et al., 2008; Torres \& GoreFelton, 2007).

\section{Kesimpulan}

Ada beberapa kesimpulan yang dapat dilihat dari penelitian ini. Pertama, harga diri seksual dan kompulsivitas seksual memiliki pengaruh bagi orang dengan HIV/AIDS untuk melakukan perilaku seks berisiko seperti hubungan seks usia dini, banyaknya pasangan seks yang dimiliki dalam kurun waktu enam bulan terkhir, 
dan hubungan seks dengan orang asing. Kedua, harga diri seksual yang terkait dengan kompetensi seksual individu memainkan peranan yang lebih penting bagi individu untuk terlibat dalam perilaku seks berisiko. Ketiga, kompulsivitas seksual, meskipun masih berada dalam taraf sedang, juga memainkan peranan penting hingga individu melakukan perilaku seks berisiko.

\section{Saran}

Terdapat beberapa saran terkait dengan hasil penelitian ini. Pertama, penting artinya mempertimbangkan keberadaan variabel kepribadian sebagai salah satu aspek internal yang mungkin memengaruhi individu hingga terlibat dalam perilaku seks berisiko. Kedua, penelitian selanjutnya dapat mempertimbangkan penerimaan diri dan adaptasi individu sebagai orang dengan HIV/AIDS dengan status kesehatan seksnya tersebut sebagai salah satu faktor yang mungkin juga memengaruhi perilaku seks berisiko yang dilakukan. Ketiga, memperluas jangkauan kota asal partisipan yang juga dapat menambah jumlah partisipan sehingga hasil yang didapat menjadi lebih komprehensif, dan keempat, penambahan materi sosialisasi pendampingan serta tritmen khusus terhadap komunitas orang dengan HIV/AIDS berkaitan dengan peran faktor internal yang kuat seperti harga diri seksual dan kompulsivitas seksual terhadap dilakukannya perilaku seks berisiko.

\section{Kepustakaan}

Aluja, A., \& Garcia, L. F. (2005). Sensation seeking, sexual curiosity, and testosterone in inmates. Neuropsychobiology, 51, 28-33. Diunduh dari: http://www. ncbi.nlm.nih.gov/pubmed/15627810
Berberovic, D. (2013). Sexual compulsivity comorbidity with depression, anxiety and substance use in students from Serbia and Bosnia and Herzegovina. Europe's Journal of Psychology, 9, 517530.

http://dx.doi.org/10.5964/ ejop.v9i3.595

Binggeli, A. L. (2005). How risky behaviors, protective factors and selected theory of planned behavior constructs influence age of sexual debut among high school students in the city of San Bernardino, California. (Dissertation, unpublished). San Bernardino: Loma Linda University.

Binson, D., Woods, W. J., Pollack, L., Paul, J., Stall, R., \& Catania, J. A. (2001). Differential HIV risk in bathhouses and public cruising areas. American Journal of Public Health, 91, 1482-1486. Diunduh dari: http://www.ncbi.nlm. nih.gov/pubmed/ 11527785

Boden, J. M., \& Horwood, L. J. (2006). Selfesteem, risky sexual behavior, and pregnancy in New Zealand birth cohort. Archive Sexual Behavior, 35(5), 549-560. Diunduh dari: http://www. ncbi.nlm.nih.gov/pubmed/17053998

Brassard, A., Dupuy, E., Bergeron, S., \& Shaver, P. R. (2015). Attachment insecurities and women's sexual function and satisfaction: The mediating roles of sexual self-esteem, sexual anxiety, and sexual assertiveness. Journal of Sex Research, 52, 110-119. http://dx.doi.org/10.1080/ 00224499.2013.838744.

Cooperman, N. A., Arnsten, J. H., \& Klein, R. S. (2007). Current sexual activity and risky sexual behavior in older men with or at risk for HIV infection. AIDS Education and Prevention, 19, 321333. Diunduh dari: http://www.ncbi. nlm.nih.gov/pubmed/ 17685845 
Dodge, B., Reece, M., Cole, S. L., \& Sandfort, T. G. M. (2004). Sexual compulsivity among heterosexual college students. Journal of Sex Research, 41, 343-350. Diunduh dari: http://www.ncbi.nlm.nih.gov/pubmed $/ 15765274$

Fernandez-Esquer, M. E., Atkinson, J., Diamond, P., Useche, B., \& Mendiola, R. (2004). Condom use self-efficacy among U.S.- and foreign-born Latinos in Texas. Journal of Sex Research, 41(4), 390-399. Diunduh dari: http:// www.ncbi.nlm.nih.gov/pubmed/ 15765279

Giugliano, J. R. (2008). Sexual impulsivity, compulsivity or dependence: An investigative inquiry. Sexual Addiction $\mathcal{E}$ Compulsivity, 15, 139-157. http:// dx.doi.org/ 10.1080/10720160802035600

Grello, C. M., Welsh, D. P., \& Harper, M. S. (2006). No strings attached: The nature of casual sex in college students. The Journal of Sex Research, 43, 255-267. Diunduh dari: http://www.ncbi.nlm. nih.gov/pubmed/17599248

Guin, A. H. (2005). Sexual risk behavior in college students: Does the parent-college student relationship impact students' condom use? (Dissertation, unpublished). Raleigh: North Carolina State University.

He, N., Detels, R., Chen, Z., Jiang, Q., Zhu, J., Dai, Y., Wu, M., Zhong, X., Fu, C., \& Gui, D. (2006). Sexual behavior among employed male rural migrants in Shanghai, China. AIDS Education and Prevention, 18(2), 176-186. Diunduh dari: http://www.ncbi.nlm.nih.gov/ pubmed/16649962

Kalichman, S. (2011). Sexual compulsivity scale. Dalam Fisher, T.D., Davis, C.M., Karber, W. L., dan Davis, S. L. (Eds.), Handbook of sexuality-related measures (third edition). New York: Routledge.
Kalichman, S., \& Rompa, D. (1995). Sexual sensation seeking and sexual compulsivity scales: Reliability, validity, and predicting HIV risk behavior. Journal of Personality Assessment, 65, 586-601. Diunduh dari: http://www.ncbi.nlm. nih.gov/pubmed/ 8609589

Kalichman, S., \& Cain, D. (2004). The relationship between indicators of sexual compulsivity and high risk sexual practices among men and women receiving services from a sexually transmitted infection clinic. Journal of Sex Research, 41, 235-241. Diunduh dari: http://www.ncbi.nlm. nih.gov/pubmed/15497052

Kebijakan AIDS Indonesia. (2015). Outlook 2015: Kebijakan penanggulangan HIV $\mathcal{E}$ AIDS di Indonesia. http://www. kebijakanaidsindonesia.net/id/beranda /49-general/1062-outlook-2015kebijakan-penanggulangan-hiv-aidsdi-indonesia. tanggal 2 November 2015.

Kvalem, I. L., Traeen, B., Lewin, B., \& Stulhofer, A. (2014). Self-perceived effects of internet pornography use, genital appearance satisfaction, and sexual self-esteem among young Scandinavian adults. Cyberpsychology: Journal of Psychosocial Research on Cyberspace, 8, 5-22. http://dx.doi.org/ 10.5817/СР2014-4-4

Lewis, M. A., Litt, D. M., Cronce, J. M., Blayney, J. A., \& Gilmore, A. K. (2014). Underestimating protection and overestimating risk: Examining descriptive normative perceptions and their association with drinking and sexual behaviors. Journal of Sex Research, 51, 86-96. http://dx.doi.org/ 10.1080/00224499.2012.710664

Mayers, K. S., Heller, D. K., \& Heller, J. A. (2003). Damaged sexual self-esteem: A 
kind of disability. Sexuality and Disability, 21, 269-276.

McBride, K. R., Reece, M., \& Sanders, S. A. (2008). Using the Sexual Compulsivity Scale to predict outcomes of sexual behavior in young adults. Sexual Compulsivity $\mathcal{E}$ Addiction, 15, 97-115. http://dx.doi.org/10.1080/107201608020 35816

McCabe, M. P., \& Taleporos, G. (2003). Sexual esteem, sexual satisfaction, and sexual behavior among people with physical disability. Archives of Sexual Behavior, 32, 359-369. Diunduh dari: http://www.ncbi.nlm.nih.gov/pubmed /12856897

Neilands, T. B., Steward, W. T., \& Choi, K. H. (2008). Assessment of stigma towards homosexuality in China: A study of men who have sex with men. Archives of Sexual Behavior, 37, 838-844.

Diunduh dari: http://www.ncbi.nlm. nih.gov/pubmed/18274889

Parsons, J. T., Kelly, B. C., Bimbi, D. S., DiMaria, L., Weinberg, M. L., \& Morgenstern, J. (2008). Explanations for the origins of sexual compulsivity among gay and bisexual men. Archives of Sexual Behavior, 37, 817-826. Diunduh dari: http://www.ncbi. nlm.nih. gov/pubmed/17882541

Parsons, J. T., Grov, C., \& Golub, S. A. (2012). Sexual compulsivity, cooccuring psychosocial health problems, and HIV risk among gay and bisexual men: Further evidence of a syndemic. American Journal of Public Health, 102, 156-162. http://dx.doi.org/ 10.2105/AJPH.2011.300284

Robinson, M. L., Holmbeck, G. N., \& Paikoff, R. (2007). Self-esteem enhancing reasons for having sex and the sexual behaviors of African American adolescents. Journal of Youth
Adolescence, 36, 453-464. http:// dx.doi.org/10.1007/s10964-006-9116-8

Rahardjo, W. (2008). Perilaku seks pranikah pada mahasiswa pria: Kaitannya dengan sikap terhadap tipe cinta eros dan ludus, dan fantasi erotis. Indigenous: Jurnal Ilmiah Psikologi, 10, 3-18.

Rahardjo, W. (2009). Sikap terhadap tipe cinta eros dan ludus, fantasi erotis, dan perilaku seks pranikah pada mahasiswa pria yang sudah pernah berhubungan seks. Jurnal Psikologi Indonesia, 6, 97-106.

Rahardjo, W. (2011). Kecenderungan tipe cinta eros dan ludus dan orientasi sosioseksual global pada pria heteroseksual lajang. Jurnal Ilmiah Psikologi, 4, 125-136.

Rahardjo, W. (2011a). Risky sexual behavior in heterosexual and gay men: Its relation to the attitude of condom use. Unpublished proceeding. Padjadjaran International Conference of Psychology (PICP) di Hilton Hotel, Bandung, Jawa Barat, 23-26 October 2011.

Rahardjo, W. (2013). Model perilaku seks berisiko pada pria. (Disertasi, tidak dipublikasikan). Yogyakarta: Fakultas Psikologi Universitas Gadjah Mada.

Rahardjo, W., \& Salve, H.R. (2014). Hubungan orang tua - anak, kelekatan teman sebaya, dan usia melakukan hubungan seks pertama kali pada mahasiswa. Makalah. Seminar Nasional Ketahanan Nasional sebagai Aset Bangsa di Fakultas Psikologi Universitas Merdeka Malang, Jawa Timur, 21 Juni 2014.

Rahardjo, W., Saputra, M., \& Hapsari, I. (2015). Harga diri, sexting dan jumlah pasangan seks yang dimiliki oleh pria lajang pelaku perilaku seks berisiko. Jurnal Psikologi, 42, 101-114. Diunduh dari: http://jurnal.ugm.ac.id/jpsi/article/ view/7172 
Reece, M., \& Dodge, B. (2004). Exploring indicators of sexual compulsivity among men who cruise for sex on campus. Sexual Addiction \& Compulsivity, 11, 87-113. http://dx.doi.org/ 0.1080/10720160490521222

Schick, V. R., Calabrese, S. K., Rima, B. N., \& Zucker, A. N. (2010). Genital appearance dissatisfaction: Implications for women's genital image selfconciousness, sexual esteem, sexual satisfaction, and sexual risk. Psychology of Women Quarterly, 34, 394-404. http://dx.doi.org/10.1111/j.14716402.2010.01584.x

Schnarrs, P. W., Rosenberger, J. G., Satinsky, S., Brinegar, E., Stowers, J., Dodge, B., \& Reece, M. (2010). Sexual compulsivity, the internet, and sexual behaviors among men in a rural area of the United States. AIDS Patient Care and STDs, 9, 563-569. Diunduh dari: http://www.ncbi.nlm.nih.gov/pubmed /20731609

Shuper, P. A., Joharchi, N., \& Rehm, J. (2014). Personality as predictor of unprotected sexual behavior among people living with HIV/AIDS: A systematic review. AIDS Behavior, 18, 398-410. http://dx.doi.org/10.1007/ s10461-013-0554-5

Simbayi, L. C., Kalichman, S.C., Jooste, S., Cherry, C., Mfecane, S., \& Cain, D. (2004). Risk-factors for HIV-AIDS among youth in Cape Town, South Africa. AIDS and Behavior, 9, 53-61. Diunduh dari: http://www.ncbi.nlm. nih.gov/pubmed/15812613

Smolenski, D. J., Ross, M. W., Risser, J. M. H., \& Rosser, B. R. S. (2009). Sexual compulsivity and high-risk sex among Latino men: The role of internalized homonegativity and gay organizations. AIDS Care, 21, 42-49. http:// dx.doi.org/10.1080/ 09540120802068803
Snell, W. E., Jr. (1998). The Multidimensional Sexual Self-Concept Questionnaire. Dalam C.M. Davis, W.L. Yarber, R. Baurerman, G. Schreer, dan S.L. Davis (Eds.), Sexuality-related measures: A compendium (2nd ed.). Thousand Oaks: Sage.

Snell, W. E. Jr., Fisher, T. D., \& Schuh, T. (1992). Reliability and validity of the Sexuality Scale: A measure of sexualesteem, sexual-depression, and sexualpreoccupation. Journal of Sex Research, 29, 261-275. Diunduh dari: https:// www.jstor.org/stable/ 3812632?seq= 1\#page_scan_tab_contents

Stupiansky, N. W., Reece, M., Middlestat, S. E., Finn, P., \& Sherwood-Laughlin, C. (2009). The role of sexual compulsivity in casual sexual partnerships among college women. Sexual Addiction $\mathcal{E}$ Compulsivity, 16, 241-252. http://dx.doi.org/10.1080/1072016090320 2760

Torres, H. L., \& Gore-Felton, C. (2007). Compulsivity, substance use, and loneliness: The loneliness and sexual risk model (LSRM). Sexual Addiction $\mathcal{E}$ Compulsivity, 14, 63-75. Diunduh dari: http://www.tandfonline.com/doi/abs/10. 1080/10720160601150147\#.V1uIeI9OKP8

van Bruggen, L. K., Runtz, M. G., \& Kadlec, H. (2006). Sexual revictimization: The role of sexual self-esteem and dysfunctional sexual behaviors. Child Maltreatment, 11, 131-145. http:// dx.doi.org/10.1177/1077559505285780

Woolf-King, S. E., Rice, T. M., Truong, H. H. M., Woods, W. J., Jerome, R. C., \& Carrico, A. W. (2013). Substance use and HIV risk behavior among men who have sex with men: The role of sexual compulsivity. Journal of Urban Health: Bulletin of the New York Academy of Medicine, 90, 948-952. http:// dx.doi.org/0.1007/s11524-013-9820-0. 
Jurnal Psikologi

Volume 43, Nomor 1, 2016: 52 - 65 